Janja MIKULAN KILDI*

\title{
KONFLIKTI IN KRIZE V LIBANONU: IMPLIKACIJE SEKTAŠKEGA POLITIČNEGA MODELA**
}

Povzetek. Pričujoči članek prikaže, kako so številni konflikti in krize $v$ Libanonu posledice odpornega sektaškega političnega sistema, ki se ohranja tudi s pomočjo transnacionalnih, predvsem regionalnih, sil. Klientelističen, koruptiven in popolnoma neodgovoren sistem, ki temelji na delitvi moči med osrednjimi verskimi skupnostmi/sektami - suniti, šiti in kristjani/ maroniti, je uspel prodreti globoko v različne družbene podsisteme: političnovarnostnega, socioekonomskega, civilnodružbenega in ideološkega. Članek na podlagi kritičnega pregleda literature in poglobljenih intervjujev z relevantnimi akterji $v$ Libanonu analizira številne dinamike in mehanizme - širjenje neučinkovitega javnega sektorja, slabljenje (večine) državnih institucij, klientelizem in disciplinske tehnike sistema, represijo, infiltracijo ali kooptacijo civilnodružbenih organizacij, sektarianizacijo; ti so vladajočemu razredu omogočili njegovo stalno reprodukcijo in krepitev.

Ključni pojmi: Libanon, politika, varnost, represija, klientelizem, civilna družba, sektarianizacija

\section{Uvod}

4. avgusta 2020 je v bejrutskem pristanišču odjeknila silovita eksplozija, zaradi katere je umrlo več kot 200 ljudi, na tisoče je ranjenih, več sto tisoč jih je ostalo brez domov. Čeprav naj bi eksplozijo povzročilo nepravilno skladiščenje skoraj 3.000 ton amonijevega nitrata, vsi indici nakazujejo, da je osrednji krivec travmatičnega dogodka politična elita sekt, ki jo karakterizirajo slabo upravljanje, klientelizem in korupcija v zadnjih treh desetletjih.

* Dr. Janja Mikulan Kildi, docentka, Fakulteta za uporabne družbene študije, Nova Gorica, Slovenia.

** Izvirni znanstveni članek. DOI: 10.51936/tip.58.1.88-111 
Na eni strani je konsociacijski politični sistem ${ }^{1}$ Libanona, ki se pogosto dojema kot primeren politični model za pokonfliktne in t.i. "globoko razdeljene družbe«, uspel zaščititi pluralizem, varuje sorazmerno visoke ravni svobode izražanja in združevanja, omogoča nekatere demokratične institucije in prakse, spodbuja zmerno politiko in preprečuje nadvlado ene same skupine pri upravljanju države. Na drugi strani pa se pojavlja vedno več kritik konsociacijskega sistema, ki v praksi običajno ne prispeva k pričakovani stabilnosti in demokraciji. Na splošno so glavne kritike tovrstnega sistema povezane predvsem z njegovo težnjo po ustvarjanju političnih zastojev in vladne neučinkovitosti, institucionalizacijo polariziranih identitet, opolnomočenjem etničnih elit, ki so sodelovale pri konfliktih in nezmožnostjo reševanja konfliktov (Roeder in Rothchild, 2005; Jarstad, 2009; Makdisi in El-Khalil, 2013; McCulloch, 2014). Tovrstni izzivi močno odzvanjajo tudi na primeru Libanona.

Čeprav so eksplozija in njene posledice šokirale Libanon, regijo in mednarodno skupnost, je za Libanonce in poznavalce omenjene države jasno, da gre v tem primeru za še eno v vrsti številnih političnih, varnostnih in socioekonomskih kriz in katastrof, ki Libanon obremenjujejo že skoraj pol stoletja. Libanon že desetletja pretresajo tudi različni konflikti in ostali varnostni incidenti - od petnajstletne državljanske vojne in številnih konfrontacij med Izraelom in Libanonom (predvsem Hezbolahom) do političnega nasilja (npr. atentat na bivšega predsednika vlade leta 2005) in lokaliziranih spopadov (v letu 2018 je npr. prišlo do 3701 nasilnega incidenta) (Lebanon Support, 2019). Članek prikaže, da je vzrok teh konfliktov in kriz, skupaj z demokratičnim deficitom, kombinacija številnih dinamik in mehanizmov političnega sistema, s fokusom na sektarianizaciji. »Sektarianizacija pomeni, da ključni akterji, kot so državne elite, proksi akterji in milice na terenu, manipulirajo in gradijo etno-religijske identitete, običajno s pomočjo skrajnega nasilja, z namenom razdelitve družbe in sledenja lastnim strateškim interesom " (Nagle and Clancy, 2019: 2). Proces sektarianizacije običajno vodi v hitro krepitev in politizacijo sektaških identitet, ki postanejo osnova za skupinsko mobilizacijo (Nagle and Clancy, 2019). V Libanonu se posledice tovrstnih dinamik odražajo v neučinkovitih institucijah in slabemu upravljanju (finančna kriza, visok nacionalni dolg, pogoste prekinitve oskrbe z električno energijo in vodo, kopičenje odpadkov in degradacija okolja), spodkopavanju meritokracije, političnemu mirovanju, ekskluzivnih

1 Konsociacijski politični model, o katerem je prvi začel pisati Lijphart (1959), predvideva sodelovanje elit, ki naj bi preprečilo družbene delitve. Elite naj bi politične konflikte reševale na podlagi kompromisa ali sporazumnega dogovora. Konsociacijske demokracije naj bi tako vključevale velike koalicije ter sorazmernost tako v volilnem sistemu kot pri delitvi javnih služb in omejenih virov. Elita vsakega družbenega segmenta naj bi imela tudi svoje področje vpliva bodisi s teritorialnega ali javno-političnega vidika (Makdsis in El-Khalil, 2013). 
in razdeljevalnih politikah, konfliktih, naraščajočih ravneh brezposelnosti, neenakosti in revščine, korupciji, političnemu kriminalu, intenzivnemu vpletanju zunanjih sil itd. Model je institucionaliziral in okrepil sektaštvo v političnih in družbenih sferah, ki voditeljem sekt omogoča, da državo in svoje volivce tretirajo kot talce svojih oportunističnih interesov ter gradijo taktično političnovarnostno in socialnoekonomsko okolje, $\mathrm{v}$ katerem so se ljudje prisiljeni zanašati na alternativne (sektaške) socialne in varnostne pokroviteljske mreže.

Tekom raziskave smo uspeli identificirati različne mehanizme in dinamike v družbenih podsistemih, ki so predstavljeni v Sliki 1 ter bodo podrobneje analizirani $\mathrm{v}$ članku. Raziskava je bila opravljena na podlagi kritičnega pregleda literature in terenske raziskave ${ }^{2}$, ki je obsegala izvedbo 22 poglobljenih intervjujev z relevantnimi akterji $v$ Libanonu leta 2016: trije predstavniki varnostnih institucij (policija - intervju 1, vojska - intervju 2, generalni sekretariat - intervju 3); predstavnik ministrstva za notranje zadeve - intervju 4; trije predstavniki političnih strank - intervjuji 5, 6 in 7; štirinajst predstavnikov civilnodružbenih organizacij (strokovnjak raziskovalnega centra v Bejrutu - intervju 8; profesorica politologije na American University of Beirut (AUB) in predstavnica civilne družbe - intervju 9; profesor na 90 Sagesse University (Faculty of Law) - intervju 10; predstavnica mednarodne nevladne organizacije - intervju 11; predstavnica libanonske nevladne organizacije - intervju 12; predstavnik libanonske nevladne organizacije - intervju 13; predstavnica libanonske nevladne organizacije - intervju 14; predstavnik libanonske nevladne organizacije - intervju 15; predstavnik delegacije EU-ja v Libanonu - intervju 16; profesorji na AUB - intervju 17, 18, 19, 20; profesor na Lebanese University - intervju 21; profesor na Georgetown University - intervju 22). Zaradi političnega in varnostnega konteksta $\mathrm{v}$ Libanonu sogovorniki ostajajo anonimni.

\section{Znanstveni prispevek članka}

Vsebina članka temelji na kritičnem pregledu literature in virov ter poglobljenih intervjujih, njegov osrednji cilj pa je obravnavati nekatere prepoznane konceptualne in metodološke vrzeli, ki onemogočajo celovit vpogled v kompleksno družbeno-politično dogajanje v Libanonu. Čeprav številni znanstveniki ugotavljajo, da je politična nestabilnost tesno povezana z obstoječim konfesionalnim modelom delitve oblasti, še vedno obstaja veliko nestrinjanj glede ključnih korenin številnih konfliktov in kriz ter

2 Terenska raziskava je bila opravljena za potrebe doktorske disertacije z naslovom Towards framework conditioning divergent regimes across Middle East and North Africa: Navigating between authoritarianism and democratization (Mikulan Kildi, 2020). Glede podrobnosti intervjujev se lahko obrnete na avtorico. 
pomanjkanje raziskav, ki bi skušale zaobjeti kompleksnost in mehanizme sektaštva. Nekatere ključne omejitve obstoječe znanstvene literature obsegajo naslednje elemente:

I. prevladujoče percepcije o Libanonu kot "globoko razdeljeni družbi«, s čimer se fokus preusmerja na (ostre) delitve, ki nastajajo na podlagi identitete in njihove posledice, medtem ko se zanemarja nekatere druge (horizontalne) razcepe, predvsem pa pomen seštevka številnih (političnih, socialnih, ekonomskih) delitev, ki jih spodbuja politična elita;

II. sektaštvo je postalo dominanten analitičen okvir za raziskovanja konfliktov, kar je privedlo do dveh osrednjih pristopov k razreševanju konfliktov: institucionalni pristop, ki zagovarja vzpostavitev konsociacijskega političnega modela, in pristop civilne družbe, ki zagovarja mirovne iniciative in medreligijski dialog. A določeni avtorji (Ghalioun, 1979; 2012; Hanafi, 2012; Majed, 2019; 2020) prepričljivo nakažejo, da tovrstno razumevanje sektaštva (zgolj) z vidika kulture in/ali religije, identitet sekt kot vzroka/neodvisne spremenljivke za konflikte, sekt kot homogenih enot analize ter nezmožnost ločevanja med družbenimi in političnimi identitetami ne zmore pojasniti kompleksnih politično-družbenih dinamik, temveč da je sektaštvo predvsem politična praksa (samo)kategorizacije;

III. veliko raziskav, ki sicer priznavajo in razkrivajo kompleksnost delovanja političnih/sektaških dinamik, ima poglobljen, a precej parcialen fokus, ki tovrstne dinamike analizira predvsem $\mathrm{z}$ vidika zagotavljanja javnih storitev (elektrika, zdravstvena oskrba, finance, varnost itd.) in infrastrukture (Cammett in Issar, 2010; Egan in Tabar, 2016; Nucho, 2017; De Elvira et al., 2019), "šibke« države (Atzili, 2010; Egan in Tabar, 2016) in/ali sistemske korupcije (Adwan, 2004; Leenders, 2016; Haase, 2018; De Elvira et al., 2019).

Na podlagi tega se članek umešča v sklop (novejše) obstoječe znanstvene literature (Baytiyeh, 2019; Fakhoury, 2019; Geha, 2019; Ghalioun, 2012; Majed, 2020; Nagle, 2016; Nagle in Clancy, 2019; Salloukh, 2015; 2019), ki meri k preseganju tradicionalnih predpostavk in razlag o sektah in sektaštvu ter tudi domnev, ki so prisotne v teorijah o konsociacijskemu modelu demokracije oz. delitve moči kot instrumentu, ki naj bi pripomogel k izgradnji miru in države, tako da skuša:

I. upoštevati različne dinamike - politične, varnostne in socioekonomske: povojno širjenje neučinkovitega javnega sektorja; namerno slabljenje večine državnih institucij; klientelizem/mafijski sistem; izključujoč razvoj; represija itd. brez izolacije zgolj nekaterih (ideoloških) vidikov;

II. demonstrirati, da ima razumevanje sekt in sektaštva s kulturnega vidika številne omejitve in da $\mathrm{h}$ konfliktom in krizam v Libanonu v največji meri prispeva mehanizem »sektarianizacije«, v okviru katerega »ključni akterji 
manipulirajo in gradijo etno-religijske identitete« (Nagle and Clancy, 2019);

III. infiltracijo sektaškega političnega sistema predstaviti na čim bolj holističen in poglobljen način z analizo konkretnih mehanizmov v različnih družbenih podsistemih in ob upoštevanju regionalnih vplivov. Predvsem kulminacija teh mehanizmov in njihovih implikacij namreč prispeva $\mathrm{k}$ reprodukciji in h krepitvi vladajočega političnega režima, ki svojim prebivalcem ne uspe zagotoviti varnega in dostojnega življenja z enakopravnimi političnimi pravicami in civilnimi svoboščinami.

Osrednje ugotovitve članka naj ne bi vplivale zgolj na teoretske predpostavke o prednostih in slabostih konsociacijskega modela demokracije, temveč bi lahko ponudile tudi relevantne perspektive za razumevanje dinamik, ki jih skušajo tematizirati teorije o izgradnji miru (peacebuilding) in izgradnji države (state-building).

\section{Slika 1: DINAMIKE IN MEHANIZMI DRUŽBENIH PODSISTEMOV V LIBANONU}

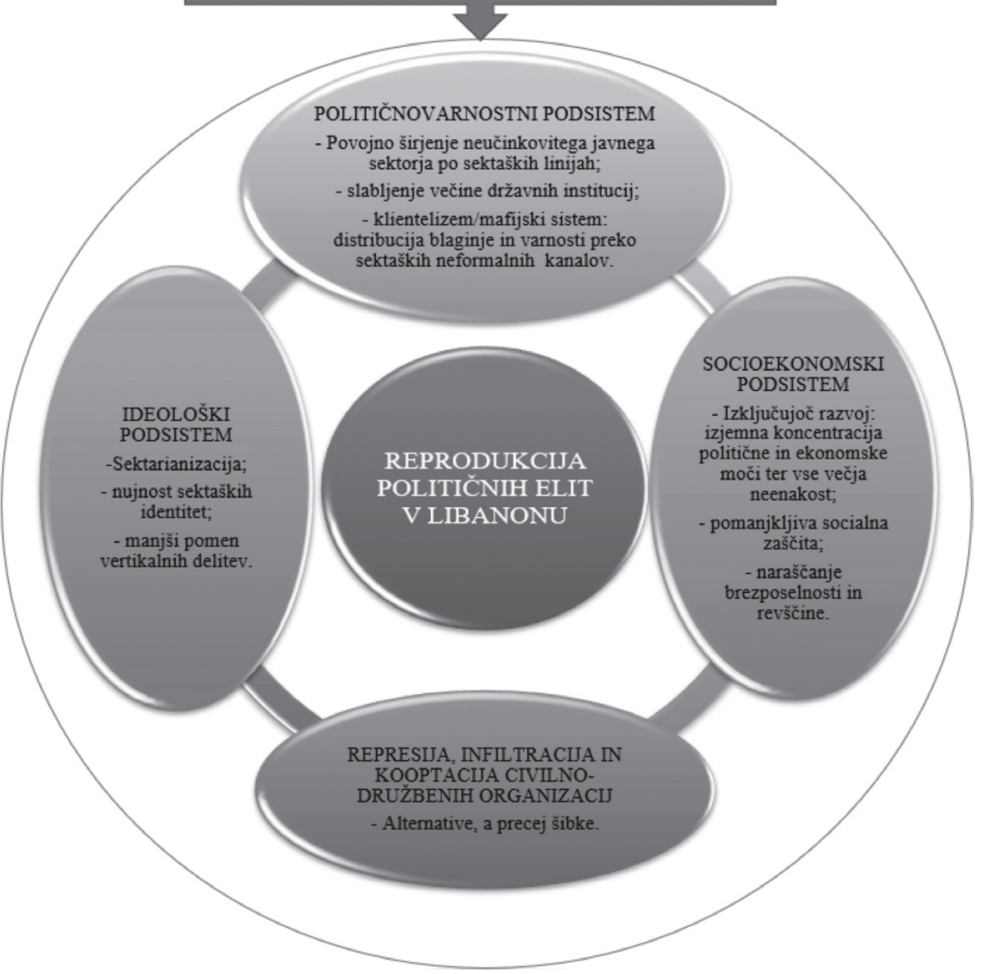

Vir: Mikulan Kildi (2020) in lastni prikaz. 


\section{Ključne dinamike in izzivi političnovarnostnega podsistema}

Korenine današnjih konfliktov in kriz v Libanonu izhajajo še iz časa francoske dominacije (1923-1943) in okrepljene ob koncu državljanske vojne (1989/90). Že od osamosvojitve leta 1943 je politični sistem Libanona namreč temeljil na konsociacijskem modelu, natančneje dogovoru o delitvi moči med tamkajšnjimi verskimi skupnostmi. Dogovor je bil vključen v neformalni nacionalni pakt (1943), ki je določil delitev parlamentarnih sedežev med krščansko in muslimansko skupnostjo na podlagi razmerja šest (kristjani/maroniti) proti pet (muslimani). Čeprav je pakt predvidel tudi enako zastopanost na položajih v vladnem kabinetu in javnemu sektorju, je maronitska skupnost kljub temu uživala določene politične privilegije, ki so izhajali že iz časa francoske dominacije (Salibi, 1990). Čeprav tovrstna politična ureditev ni mogla preprečiti dolgotrajne državljanske vojne (19751990) in je celo prispevala k številnim konfliktom med vojno, je bilo načelo delitve moči po sektah ponovno uveljavljeno tudi v t.i. sporazumu iz Tajfa, s katerim se je končala državljanska vojna. Sporazum je prilagodil delitev moči med tremi osrednjimi verskimi skupnostmi oz. sektami, ki so prevzele tri najvišje politične položaje v državi: predsednik republike tako vedno prihaja iz maronitske skupnosti, predsednik vlade je sunit, predsednik parlamenta pa šiit. Sporazum zahteva tudi enakomerno porazdelitev parlamentarnih sedežev med kristjani in muslimani ter mest na najvišjih položajih v javnem sektorju. Poleg tega imajo tudi štiri druge sektaške skupnosti - druzi, ortodoksni kristjani, grški katoličani in Armenci - zagotovljene ministrske položaje v vladi. Sporazum je hkrati zmanjšal izvršilno moč krščanskega predsednika republike ter okrepil vlogo sveta ministrov, ki jim predseduje sunitski predsednik vlade in parlamentarne zbornice, ki jo vodi šiitski predsednik parlamenta (Harris, 2016: 98).

A v praksi in v nasprotju z novo ustavo se dodeljevanje mest po deležih sekt ne odraža zgolj na najvišjih položajih, tako kot v predvojnem obdobju, temveč pri zaposlovanju v celotnem javnem sektorju, tudi na nižjih birokratskih mestih. Zaposlovanje v javnem sektorju je tako postalo del kompleksnega sistema, ki ščiti politične, ekonomske in varnostne pristojnosti elite sekt in njihovih zaveznikov (Salloukh, 2019).

Med vzroki številnih konfliktov in kriz je tudi dejstvo, da so bili ob koncu državljanske vojne v libanonsko vlado integrirani številni t.i. vladarji vojne ${ }^{3}$, ki so tako vse do danes zasedali pomembne politične in vojaške pozicije, $s$ čimer se je v povojnem obdobju zagotovila izjemno »visoka stopnja kontinuitete elit in nizka stopnja njihove prepustnosti« (van Veen, 2015: 15). Med

3 Walid Jumblatt (druz), Nabil Berri in Hassan Nasrallah (oba šiita), Michel Aoun in Amin Gemayel (oba kristjana) (van Veen, 2015). 
njimi so npr. tudi današnji predsednik republike $M$. Aoun in predsednik parlamenta N. Berri. Nizke ravni zaupanja med posameznimi političnimi elitami, skupaj z nadzorom Sirije v prvih povojnih letih, so kreirale politično okolje, v katerem so si elite sekt in "vladarji vojne« razdelili (divided) in ne delili (share) moč (Makdisi in El-Khalil, 2013; intervju 11, 2016; Salloukh, 2019). Kot sta poudarila Makdisi in El-Khalil (2013), se je povojno konfesionalno politično vodstvo - z nekaj izjemami - ukvarjalo predvsem s prizadevanjem, da bi obstali na oblasti, in ne z graditvijo osnov za dobro upravljanje države. Politično prevlado vladajočega razreda so omogočili mehanizmi, kot so prilagojeni volilni zakoni, množično zaposlovanje osebja v vojski in upravi iz vrst nekdanjih milic in/ali zvestih privržencev ipd. V takšnem političnem okolju so se razvile visoke stopnje korupcije, nepotizma, klientelizma in politične neodgovornosti ter varovanje zasebnih na račun javnih interesov (Makdisi in El-Khalil, 2013; Salloukh, 2020).

Vnaprej določena konfesionalna delitev moči tako ni prispevala k robustnemu in funkcionalnemu vladnemu sistemu, temveč je generirala t.i. politični fevdalizem, $v$ katerem so politične elite sekt postale nepogrešljivi oligopolistični pokrovitelj svojih klientskih volilnih enot (Salamey in Payne, 2008). Za državo v Libanonu se uporablja fraza "dawlat al-muhasasa« ali 94 »dodelitvena država« oz. država, v kateri je delitev javnih funkcij, privilegijev in državnih virov podrejena elitam sekt (Salloukh, 2019).

Politične reforme, ki so bile sprejete $v$ sporazumu iz Tajfa, so tako ustvarile povojni paradoks: sicer bolj uravnotežen konsociacijski dogovor o delitvi moči, ki pa je privedel do še večjega, bolj klientelističnega, bolj koruptivnega in manj avtonomnega javnega sektorja, ki ga okupirajo plenilske rentierske prakse po sektaških in klientelističnih linijah. (Salloukh, 2020: 43)

Soočeni z nenehnimi političnimi izzivi, slabimi javnimi dobrinami in storitvami ter različnimi oblikami nasilja prebivalci Libanona svojih politikov niso pozvali, naj njihove interese zastopajo v formalnih okvirih države, temveč so se prilagodili na slabo delovanje države z znižanjem pričakovanj, izogibanjem državnemu aparatu in zatekanju k zasebnim alternativam oz. k wast $i^{4}$. Celotne skupnosti se tako obračajo $\mathrm{k}$ lokalnim in izključujočim političnim voditeljem sekt in celo iščejo tujo podporo (Salamey, 2009; intervju 11, 2016). Velik del prebivalstva je sprejel in ponotranjil neformalna pravila igre, po katerih so osebna omrežja, pokroviteljstvo/klientelizem in korupcija

4 T. i. wasta je izjemno razširjen koncept v arabskem svetu, ki se nanaša na nepotizem oz. različne povezave (družinske, plemenske ipd.). Dobesedni pomen besede je "posredovanje "ki je povezano s posredovanjem pri alokaciji virov, privilegijev ipd. predvsem prek izogibanja uradnim kanalom (Gray, 2019). 
postala prevladujoč način delovanja in osnovna načela preživetja (Middle East Report, 2015; intervju 10, 2016; De Elvira et al., 2019). Libanonski politični model torej temelji na ideji, da voditelji sekt predstavljajo skupnosti, zagovarjajo njihove interese in regulirajo konflikte. Takšen politični sistem je generiral šibke državne institucije, ki niso zmožne zagotoviti osnovnih dobrin in pravic, medtem ko so se mreže sektaškega pokroviteljstva močno okrepile. Voditelji sekt tako niso postali samo predstavniki svojih skupnosti, temveč tudi osrednji ponudniki storitev, dobrin in služb (intervju 18, 2016; Majed, 2017; De Elvira et al., 2019).

En izmed sektorjev, v katerem so tovrstne dinamike še posebno zaskrbljujoče, je varnostni sektor. Libanoncem je varnost namreč zagotovljena skozi kompleksen hibridni varnostni sistem, ki zaobjema posebno pozicijo in odnose med osrednjimi državnimi varnostnimi institucijami ter kompleksne dinamike formalnosti in neformalnosti (van Veen, 2015; Carpi et al., 2016; Gaub, 2016; Hazbun, 2016. V okviru prvega je pomembno poudariti, da so vojska (LAF), policija (ISF) in nekatere druge varnostne institucije $v$ Libanonu, kljub določenim izzivom v smislu financ in kapacitet (intervju 1, 2016; intervju 2, 2016; intervju 3, 2016), precej močne državne institucije. Med drugimi o tem priča tudi izjemna represija proti vladnim protestnikom (Human Rights Watch, 2020). Njihova moč se manifestira predvsem v situacijah, ko njihovi posegi in represija služijo interesom političnih elit. K temu prispevajo tudi pogosto zamegljene vloge vojske in policije ter dejstvo, da vojska $v$ veliki meri opravlja tudi policijske naloge, čeprav zanje ni usposobljena. Hibridnost zagotavljanja varnosti pa se kaže tudi v kompleksnih dinamikah med formalnimi in neformalnimi dimenzijami zagotavljanja varnosti (intervju 5, 2016; intervju 6, 2016; intervju 7, 2016; intervju 8, 2016; intervju 12, 2016). Številni konflikti in varnostni incidenti namreč razkrivajo, da obstajajo številni primeri sodelovanja med državnimi in nedržavnimi akterji kot tudi primeri, ko formalni varnostni akterji svoje pristojnosti prenašajo na neformalne - državne in nedržavne - akterje.

Med najpomembnejšimi nedržavnimi varnostmi akterji so ravno politične stranke (intervju 8, 2016; intervju 9, 2016; intervju 15, 2006). Lokalna prisotnost političnih strank je običajno neformalna in razpršena, običajno pa politične stranke v tem kontekstu prevzemajo različne vloge - od konkretnih intervencij v soseščinah do nadzora akcij uradnih varnostnih institucij, predvsem vojske, policije in redarstva. Obstajajo tudi primeri, ko formalne varnostne ustanove posežejo zgolj, če dobijo privolitev določene politične stranke (Belhadj et al., 2015; van Veen, 2015; intervju 4, 2016). Korenine tovrstnih dinamik segajo v čas državljanske vojne, ko so po kolapsu vlade različne stranke in njihove sektaške milice postale osrednje predstavnice interesov ter so svojim sektaškim skupinam zagotavljale varnost in storitve. Čeprav so bile po državljanski vojni politične stranke 
uradno demilitarizirane (z izjemo Hezbolaha, ki je lahko ostal močno oborožen zaradi izraelskih groženj), so številne stranke ohranile svoje milice, ki pa so sicer precej omejene $z$ orožjem.

En vodilnih libanonskih družboslovcev Traboulsi (2014) tako meni, da se je sistem klientelizma v Libanonu transformiral iz zagotavljanja določenih storitev posameznikom in družinam k zagotavljanju množičnih storitev velikemu delu prebivalstva (Traboulsi, 2014). Ob upoštevanju teoretskih predpostavk Pina Arlacchija o konceptu "mafije« Traboulsi (2014) poudari, da se je klientelistični sistem v Libanonu, predvsem zaradi koncentracije vodstva in moči med državljansko vojno in po njej, dejansko spremenil v mafijski sistem, »kjer v sicer tradicionalni izmenjavi storitev in politične lojalnosti osrednjo vlogo prevzemata moč in nasilje« (Traboulsi, 2014: 97).

\section{Propadajoč socioekonomski podsistem}

V povojnem obdobju lahko socioekonomski razvoj Libanona razdelimo v pet večjih obdobij. V prvi fazi (1991-1994) je Libanon sprejel kratkoročno ekonomsko vizijo in bil priča hitri rasti, ki je bila rezultat povišanih izdatkov $\mathrm{v}$ javnem sektorju in investicij privatnega, predvsem gradbenega sektorja 96 (Makdisi in El-Khalil, 2013; Alami, 2013). Ambiciozni projekti rekonstrukcije, ki jih je v zgodnjih devetdesetih letih začel pokojni predsednik vlade Rafik Hariri in naj bi Libanon transformirali v turistično, nepremičninsko in finančno regijsko središče, so vladajočemu razredu z (gradbenimi) projekti zagotovili nove dobičke (Makdisi in El-Khalil, 2013; Alami, 2019). A ti ambiciozni projekti so daleč presegli naložbeno zmožnost države, zato so med drugim v veliki meri prispevali k ogromnemu državnemu dolgu (od začetka devetdesetih let do leta 2008 se je dolg povečal na 43 milijard ameriških dolarjev ali 180 odstotkov bruto domačega proizvoda) in je v letu 2019 znašal kar 87 milijard dolarjev (Alami, 2019).

V drugem obdobju (1995-2000) je Libanon že začel doživljati postopen padec rasti, ki je bil rezultat naraščajoče korupcije ter odsotnosti političnih in administrativnih reform (Makdisi in El-Khalil, 2013). V teh petih letih je prišlo do naraščanja brezposelnosti, naraščajoče vrzeli med prihodki in odhodki ter erozije ekonomskega statusa srednjega razreda. Medtem ko je v tretjem obdobju (2000-2004) prišlo do rahlega izboljšanja rasti (pribl. 5-odstotna rast), predvsem zaradi okrepljenih tokov arabskega kapitala v Libanon ter izboljšanja stanja na nepremičninskem trgu in v turizmu, je Libanon v četrtem obdobju (2005-2012) doživel valove politične in varnostne nestabilnosti ter vojaško konfrontacijo z Izraelom, kar vse je povzročilo hudo ekonomsko destrukcijo. Ta je bila prepletena z okoljsko degradacijo ter višanjem brezposelnosti, korupcije in družbene neenakosti (Makdisi, 2004; Leenders citiran v Makdisi and El-Khalil, 2013). Zaradi 
naraščajoče koncentracije politične in ekonomske moči v rokah peščice ter posledic državljanske vojne v sosednji Siriji se v zadnjih letih (2013-2019) Libanon srečuje z eno izmed največjih političnih, ekonomskih in finančnih kriz od začetka državljanske vojne.

Poslabšanje gospodarskih razmer in omejene finančne rezerve $\mathrm{v}$ ameriških dolarjih so privedli do omejitev dovoljene vrednosti dvigov ameriških dolarjev in libanonskih funtov. Kljub posredovanju Centralne banke je libanonski funt izgubil več kot 30 odstotkov vrednosti (Alami, 2019) oz. kar 80 odstotkov v letu 2020, medtem ko so cene hrane in osnovnih storitev močno narasle. Oktobra 2019 so kriza in naraščajoče frustracije zaradi socioekonomskih stisk sprožile protivladne proteste $\mathrm{v}$ okviru t.i. oktobrske revolucije, ki so bili naperjeni proti slabemu političnemu upravljanju in posledično sistemu političnih sekt. Marca 2020 pa so se ekonomskemu kolapsu pridružile še posledice pandemije virusa covid-19, predvsem zaradi zaprtja. V prvi polovici leta se je zaprlo več kot 1000 restavracij in posledično je samo v tem sektorju brez služb ostalo prek 25.000 ljudi. Zaprtje je močno prizadelo tudi turistični sektor, nekoč osrednji steber libanonske ekonomije, ter bančne ali osebne prenose denarja iz držav, kjer delajo Libanonci. Posledično je okoli 3 milijone ljudi oz. kar $65 \%$ vseh prebivalcev zdrsnilo pod prag revščine (Mounzer, 2020). Medtem ko so podatki o premoženju, bogastvu in lastnini v Libanonu izjemno skopi, je raziskava, ki jo je izvedel Traboulsi (2014), pokazala, da imata približno dve družini s šestimi odraslimi člani v lasti kar 15\% zasebnega bogastva v Libanonu.

Kot je podarila Bou Khater (2020), libanonske javne politike socialne zaščite niso bile razvite za odpravo skrajne revščine, zmanjšanje neenakosti ali razširitev državljanstva. Zgodovinsko gledano je socialna javna politika dejansko prispevala $\mathrm{k}$ dinamiki izključevanja, $\mathrm{v}$ kateri je subvencioniran zasebni sektor dobro služil višjemu in srednjemu razredu, medtem ko je država poskrbela za relativno privilegirane delavce. Nasprotno pa je večina neformalnih delavcev (sezonski delavci, gradbeni in kmetijski delavci, delavci, ki pomagajo v gospodinjstvih) in tudi samozaposlenih, brezposelnih in upokojencev ostala precej nezaščitena. Po raziskavi libanonskega statističnega urada v obdobju 2018-2019 kar 44\% prebivalcev ni uživalo nobene oblike socialne zaščite s strani države (Bou Khater, 2020). Vlada je neuspešna tudi pri preprečevanju revščine. Nacionalni program (NPTP) je od leta 2012 edini program proti revščini in program prenosa denarja $v$ Libanonu. Začel se je z začetnim proračunom v višini 28 milijonov ameriških dolarjev, a se je vlada z izbruhom gospodarske in finančne krize oktobra 2019 in pričakovano naraščajočimi stopnjami revščine za leto 2020 odločila, da proračun NPTP-ja poveča z 28 na 452 milijonov dolarjev, kar bo v celoti financirano s posojilom Svetovne banke (Bou Khater, 2020). Toda podrobnejši pregled značilnosti vpliva in omejitev NPTP-ja kaže, da program sicer 
ponuja znatno podporo najrevnejšim prebivalcem, hkrati pa so njegove dolgoročne koristi omejene, saj meri zgolj na simptome in ne zdravi vzrokov revščine in neenakosti (Bou Khater, 2020). Posledično se ljudje zanašajo na storitve, ki jih zagotavljajo akterji sekt, kar krepi klientelizem, povečuje vrzel med državljani in državo ter prispeva k reprodukciji struktur, ki so dejansko vzrok neenakosti in revščine.

\section{Dinamike med politično elito sekt in civilno družbo}

Primerjalno gledano ima Libanon eno najbolj dinamičnih in edinstvenih civilnih družb na Bližnjem vzhodu, ki močno prispeva tudi k višjim stopnjam demokratičnosti v regiji, sicer zaznamovani z raznolikimi, a še vedno številnimi in izjemno odpornimi avtoritarnimi režimi.

Protesti v zadnjih letih razkrivajo, da so med nasprotniki sistema sekt najrazličnejši segmenti družbe, od žensk, delavcev, učiteljev, uslužbencev v javnem sektorju, študentov do ostalih organizacij civilne družbe ali koalicij nevladnih organizacij. Ti aktivisti ali organizacije so bili aktivni na številnih področjih: uvedba zakona o možnosti izbire osebnega statusa; kriminalizacija vseh oblik nasilja v družini, predvsem tistega, katerega žrtve so ženske; 98 sprejem zakonodaje, ki bo ženskam omogočil, da državljanstvo prenesejo na svoje otroke in partnerje, ki prihajajo iz tujine; zagovorništvo socioekonomskih pravic najranljivejših delov prebivalstva; razkritje družbenih posledic neoliberalnih javnih politik, ki jih sprejemajo politične in ekonomske elite sekt; sprejem novega volilnega zakona, ki bo odprl možnosti za nove oblike politike mobilizacije zunaj sektaških okvirjev (Salloukh et al., 2015). Vse to so izjemno pomembna in težavna prizadevanja $v$ kontekstu boja proti politični ekonomiji in ideološki hegemoniji obstoječega sistema sekt, ki pa žal še niso pripomogla h globljim spremembam.

Podrobnejši vpogled $\mathrm{v}$ dinamike med politično elito sekt in civilno družbo razkriva, da so številne civilnodružbene organizacije (CDO), predvsem $\mathrm{z}$ izjemo bank, absorbirane $\mathrm{v}$ pokroviteljski sistem in tako prispevajo $\mathrm{k}$ ohranjanju in reprodukciji klientelističnih vzorcev in kriz. Že v začetku devetdesetih let je prišlo do pozicioniranja sindikatov po sektah, čeprav naj bi le-ti ščitili interese vseh delavcev ne glede na pripadnost sekti. Poleg tega so sektaške delitve med sindikati zmanjšale njihove sposobnosti pogajanj z vlado in zasebnim sektorjem (Makdisi in El-Khalil, 2013). Tudi Clark in Salloukh (2013: 732-744) sta poudarila, da med sektaškimi elitami in civilno družbo obstaja dinamičen in vzajemen odnos. Na podlagi analize treh študij primerov civilnodružbenih organizacij (Konfederacija za delo; Libanonski svet za ženske in Alternativne nevladne organizacije) sta zaključila, da sektaške elite uporabljajo tako formalne kot neformalne mehanizme za infiltracijo v relativno manjše civilnodružbene organizacije, s čimer jim preprečijo, 
da bi vplivali na politične in socioekonomske spremembe na nacionalni ravni. Na drugi strani pa si akterji civilne družbe prizadevajo instrumentalizirati politični sistem sekt in njegove vire za lastne organizacijske ali osebne interese (Clark in Salloukh, 2013: 732-744). V tem kontekstu ne preseneča, da tudi večina intervjuvancev, ki prihajajo iz vrst različnih političnih strank (intervju 4, 2016; intervju 5, 2016; intervju 6, 2016; intervju 7, 2016) in nevladnega sektorja (intervju 13, 2006; intervju 14, 2006), meni, da obstoječi politični model delitve oblasti ni slab in da odseva realnost na terenu ter da je problem zgolj v upravljanju samega sistema.

Posledica tovrstnih dinamik med voditelji sekt in civilno družbo je slabitev potencialne medsektaške pripadnosti in politične mobilizacije ter sabotiranje iniciativ proti sektam (Clark in Salloukh, 2013; intervju 9, 2016). To je zelo jasno razvidno tudi na primerih številnih protestov v Libanonu, ki so bili vse do oktobra 2019 izjemno fragmentirani po sektaških linijah in posledično precej neuspešni. Protesti v okviru oktobrske revolucije namreč pomenijo pomembno prelomno točko $\mathrm{v}$ zgodovini uporov predvsem zato, ker so ljudje prvič protestirali proti celotnemu vladajočemu političnemu razredu, ne glede na sekte. Poleg tega so se prvič vzpostavila nova zavezništva med najbolj revnimi razredi, ki običajno predstavljajo osrednje volilno telo sektaških političnih strank, ter delavskim in srednjim razredom (Majed, 2019). Tovrstne akcije torej kažejo, da sicer obstajajo določena nasprotovanja in alternative obstoječemu sistemu sekt, a da mehanizem kooptacije civilnodružbenih organizacij še vedno pomeni pomemben mehanizem vladajočih elit za reprodukcijo identitet različnih sekt.

\section{Ideološki podsistem: razumevanje sekt v luči sektarianizacije}

Razmeroma liberalna večverska in večsektna libanonska družba Libanon uradno priznava 18 sektaških skupin - ni le nagnjena k spodbujanju medsebojne verske strpnosti, temveč tudi k nenehnemu priznavanju, da je verska svoboda ključni element za preživetje libanonskih liberalnih tradicij (Makdisi in El-Khalil, 2013).

Kljub temu pa sektaštvo ostaja integralni del strukture moči v Libanonu. A kot že izpostavljeno, za razumevanje kompleksnih dinamik ni treba razumeti zgolj »sekt«, ki so družbeni konstrukt, temveč proces sektarianizacije, v okviru katerega politične elite instrumentalizirajo identitete sekt za dosego svojih političnih ciljev. Kot že omenjeno, je bil libanonski politični model v sporazumu iz Tajfa oblikovan na poenostavljeni predpostavki, da je bila državljanska vojna konfrontacija sekt in da je libanonska družba "globoka razdeljena" vzdolž sektaških linij ter posledično potrebuje politično rešitev, ki bo upoštevala te delitve in preprečila vnovični konflikt (Majed, 2017). A državljanska vojna, ki je pogosto predstavljena kot sektaška vojna med 
kristjani in muslimani, je bila precej kompleksnejša; bila je mozaik številnih konfliktov, ki so vključevali tako leve kot desne frakcije ter veliko število zunanjih akterjev, vključno s Palestinsko osvobodilno organizacijo (PLO), Sirijo, Izraelom in ZDA (Salibi, 1990; Nagle in Clancy, 2019).

Nadalje je problematična tudi paradigma "globoko razdeljene družbe«, ki se uporablja predvsem pri opisih povojnih držav/družb z izrazitimi vertikalnimi razcepi, ki temeljijo predvsem na določeni etnični ali sektaški identiteti. Paradigma temelji na naslednjih predpostavkah: to so družbe, v katerih so vertikalne delitve pomembnejše od vseh drugih vrst družbenih delitev, ter družbe, ki so mozaik etničnih skupin ali sekt, ki so notranje homogene in kohezivne; te vertikalne delitve so globoke in trajne; takšne delitve so torej katalizatorji nasilja, konfliktov in vojne (Smooha and Hanf, 1992; Van Den Berghe, 2002; Beiber, 2003; Guelke, 2012; Majed, 2019). Takšno razumevanje družbenih dinamik vodi k zaključku, da so tovrstne družbe »izjemne«, zato potrebujejo posebno politično rešitev - kot so modeli konsocializma, delitev moči na podlagi identitete, odcepitev ipd., ki bo zagotovila mir in stabilnost (intervju 22, 2016; Majed, 2019). A zgodovinski in aktualni vpogled v odnose med različnimi sektaškimi skupnostmi v Libanonu razkriva precej kompleksnejšo dinamiko in nasprotuje predpostavkam obstoječe 100 paradigme.

Zgodovinsko gledano, sektaštvo v Libanonu izhaja iz neenakega dostopa do različnih političnih in družbenoekonomskih položajev med dvema skupnostma v poznofevdalnem sistemu tedaj še Gore Libanon - druzi na eni strani in maroniti (ali na splošno kristjani) na drugi. Medtem ko so vladajoči in zgornji sloj (lastniki zemlje) v Gori Libanon predstavljali predvsem druzi (in pribl. 2-3 družine maronitov), je bila velika večina prebivalcev - trgovci, obrtniki, kmetje, delavci - kristjanov. Čeprav so druzi v državljanski vojni leta 1860 osvojili vojaško zmago, so zaradi zloma fevdalnega sistema, ki so ga nadzirali, doživeli padec. Medtem pa so v vojni poraženi kristjani/maroniti kljub temu pridobili obliko samovlade v Gori Libanon, kjer so predstavljali večino ter si kmalu zagotovili številne privilegije na račun preostalih sekt.

Po osamosvojitvi Libanona leta 1943 so se sektaške identitete pojavile kot ključni označevalec politične identitete in dejavnik mobilizacije. Salloukh (2020) poudari, da je kombinacija "mobilizacije od zgoraj«, ki so jo vodili kolonialni uradniki in elite sekt, ter kasnejše "mobilizacije od spodaj«, ki so jo vodile marginalizirane skupnosti, ki so zahtevale več pravnih pravic in avtonomnost, identitete sekt transformirala $\mathrm{v}$ dominantne - a nikoli edine - spodbudne strukture za politično reprezentacijo in razdelitev resursov. Rezultat je bil torej dogovor o delitvi moči, v okviru katerega je ravnotežje med sektami favoriziralo krščanske politično-ekonomske elite (Salloukh, 2020). 
Kasneje se je glavna delitev pojavila med kristjani in muslimani, danes pa je tako v Libanonu kot v regiji aktualen predvsem razkol med suniti in šiiti. A ta je v Libanonu dejansko aktualen šele od leta 2005, ko je bil Libanon znova pahnjen v obdobje nestabilnosti z veliko mero nasilja, vključno z atentatom na nekdanjega predsednika vlade Rafika Haririja, ter okrepljen vse od začetka državljanske vojne v Siriji leta 2011. Atentat, za katerega so številni obdolžili sirijskega zaveznika Hezbolaha, je sprožil proteste proti sirskim enotam, ki so bile stacionirane v Libanonu od konca državljanske vojne. Protestniki so skupaj s pritiski Združenih narodov dosegli njihov umik in s tem prekinili vlogo Sirije kot vplivnega arbitra v notranjepolitičnih sporih (Makdisi in El-Khalil, 2013). Posledično je v Libanonu prišlo do delitve države na dve glavni politični skupini: koalicijo 8. marca (usmerjena prosirijsko in proiransko) in koalicijo 14. marca (proti Siriji/Assadu). V koaliciji 8. marca prevladujejo Hezbolah in njegovi zavezniki, šiitsko gibanje Amal, krščanska stranka Free Patriotic Movement (FPM) in Progressive Socialist Party, ki zastopa druze. V koalicijo 14. marca pa so vključene sunitska stranka Future Movement ter krščanski stranki Kataeb in Lebanese Forces.

Tovrstne relativno hitre transformacije v pomembnosti sektaških mej v Libanonu tako ne potrjujejo predpostavke, da so delitve po sektah izjemno globoke ter posledično trajne in konstantno politično relevantne. Hitre preusmeritve znotraj koalicij in sestava najaktualnejših koalicij pa jasno kažejo tudi na nehomogenost in nekohezivnost sekt. Politične elite niso nujno razdeljene po obstoječih mejah med sektami, temveč jih večina med seboj tekmuje tudi znotraj iste skupnosti. Tovrstna fragmentacija je najočitnejša znotraj krščanske skupnosti, ki ne samo da jo predstavlja večje število strank, temveč se krščanske stranke povezujejo v dve ideološko popolnoma različni koaliciji. Do relevantne ugotovitve, ki nasprotuje dominantnim percepcijam o sektaštvu, prihaja tudi dolgoletna raziskovalka sekt (Majed, 2020), ki na podlagi temeljite analize uličnih mobilizacij in formacij političnih koalicij zaključuje, da procesov sektarianizacije in polarizacije dejansko ne vodijo sekte in delitve med njimi, temveč znotrajsektaška politična enotnost oz. ko je večina političnih strank, ki predstavlja določeno sekto, na isti politični strani (Majed, 2020).

Nenazadnje je pomembno poudariti, da je članstvo posameznikov v določeni sekti v Libanonu v veliki meri obvezno oz. nujno. Kot izpostavi Salloukh skupaj s soavtorji (2015), je nasilje sektaškega sistema izjemno globoko ter ne vedno razvidno ali fizično. Večina moških in žensk je tarča tehnik discipliniranja sektaškega sistema, čeprav so ženske še toliko večje žrtve. Logika tega sistema Libanoncev ne tretira kot državljanov z neodtujljivimi političnimi in socialnimi pravicami, temveč jih zreducira na neenake člane sekt, ki jih priznava država (Salloukh et al., 2015). Posamezniki tako lahko politične, socialne in izobraževalne pravice uživajo le, če so del sekte; v 
nasprotnem primeru praktično nimajo identitete (Traboulsi, 2014; Salloukh et al., 2015). Upor proti tovrstni disciplinski logiki pa vodi v kaznovanje tako v političnoekonomskem kot simbolnem smislu (Salloukh et al., 2015).

Trenutni politični sistem torej nagrajuje politično mobilizacijo na podlagi identitet posameznih sekt, pri čemer politiki uporabljajo državne resurse za ohranjanje lojalnosti med svojimi klienti. Čeprav je nova vlada pod vodstvom Diaba, ki je nastopila februarja 2020 in nato teden dni po avgustovski eksploziji v pristanišču sicer odstopila, obljubila politične spremembe, je dejansko delovala na že poznan način ter posledično ni uspela preseči globokih socioekonomskih in političnih kriz (Salloukh, 2020). V povojnem obdobju sta se nadzor in omejevanje pripadnikov določene sekte zgolj še krepila, saj so posamezne sekte (predvsem v primeru osrednjih šestih sekt) prišle pod okrilje enega posameznika. Traboulsi (2014) izpostavi, da Libanonu tako dejansko vlada "sedem velikih mož«: predstavniki t.i. troike (predsednik republike, predsednik vlade in predsednik parlamenta; slednji si vodenje deli z vodjo Hezbolaha Hassanom Nasrallahom) in štirje ostali pomembni politiki (Saad Hariri (sunit in bivši predsednik vlade), Michel Aoun (kristjan, ki je v letu 2020 sicer predsednik republike), Samir Geagea (predsednik vplivne krščanske politične stranke Lebanese Forces) in Walid

102 Jumblatt (vodja druzov oz. predsednik Progressive Socialist Party)).

\section{Implikacije geopolitičnih dinamik: med Savdsko Arabijo in Iranom}

Transnacionalni vplivi so na Libanon učinkovali že od samega nastanka države leta 1920, saj je sedanje teritorialne meje določila francoska kolonialna oblast $\mathrm{v}$ skladu s svojimi kolonialnimi interesi ter zahtevami maronitske cerkve (Salibi, 1990; Salloukh, 2020). Čeprav so se libanonske vlade pogosto slušale izogniti zunanjim povezavam in posegom, celotna moderna zgodovina Libanona priča, da so zunanje intervencije, predvsem ob političnih in varnostnih izzivih, postale konstanta $v$ libanonski politiki. Na splošno Libanon ima strateški pomen za zunanje sile. Geografsko je v jedru arabskega sveta in ima dostop do arabsko-izraelske fronte. Libanonci s svojo ogromno (pribl. 10 milijonov ljudi) ter močno in vplivno diasporo predstavljajo pomemben človeški vir tako regionalno kot globalno (Harris, 2016). K številnim intervencijam pa je prispevala tudi strukturna šibkost, ki je Libanon naredila še občutljivejšega na zunanje, predvsem regionalne intervencije. Za razrešitev konflikta iz leta 1958 je bila na primer potrebna intervencija ZDA in Egipta; leta 1969 je Kairski sporazum pripomogel k razrešitvi konflikta med libanonsko vojsko in palestinskimi oboroženimi skupinami. Poleg tega se je državljanska vojna, ki je potekala v letih 1975-1990, končala s posredovanjem regionalnih in mednarodnih sil (predvsem ZDA).

Veliko vlogo je v povojnem obdobju v Libanonu odigrala tudi Sirija. V 
obdobju 1991-2005 je imela Sirija dejansko politično in vojaško hegemonijo nad libanonskimi državnimi institucijami, notranjimi politikami in procesi odločanja. Ko predstavniki t.i. troike niso uspeli rešiti političnih sporov, so vlogo arbitra prevzele sirijske oblasti (Makdisi in El-Khalil, 2013). Leta 2005 je bil zaradi konflikta interesov med veliki silami (Savdska Arabija, Sirija, ZDA) ter protestov in pritiskov Združenih narodov dosežen dogovor o umiku sirskih vojaških enot, s čimer se je zaključila tudi sirska prevlada v Libanonu. Z umikom so določene libanonske elite izgubile pomembnega zunanjega pokrovitelja (van Veen, 2015). Čeprav je ta moment ponudil pomembno priložnost za politično transformacijo, sta se nestabilnost in nevarnost še okrepili, saj vladajoče politične elite niso odstopile od togih sektaških vzorcev delovanja. Libanonski politični sistem pa se je (deloma) uspel obdržati tudi zaradi velikih sil, predvsem Francije, ZDA in Velike Britanije, ki model delitve moči dojemajo kot stabilizacijski dejavnik, zato različnih oblik pomoči ne pogojujejo s potrebnimi reformami. S pretiranim, celo romantiziranim poudarjanjem libanonske odpornosti in pomena stabilnosti v sicer izjemno nemirni regiji (številni konflikti, vojne, humanitarne krize, protesti/revolucije in kontrarevolucije itd.) so tako prispevali k reprodukciji libanonskega vladajočega razreda.

V nadaljevanju članka se bomo osredinili predvsem na najaktualnejše geopolitične dinamike, ki jih zaznamujejo proksimalne napetosti med dvema regionalnima silama - Savdsko Arabijo in Iranom - predvsem od začetka vstaj v Siriji. V tekmi za regijsko nadvlado sta tako Savdska Arabija kot Iran uporabila številne mehanizme, ki vključujejo (versko) netolerantnost, zatiranje umetniškega izražanja in spodbujanje nasilja med sektami ter so privedli do napadov na nešteto intelektualcev, pojava skupin, kot je Hezbolah, terorističnih napadov v ZDA 11. septembra 2001, vzpona Daesha/ ISIS-a itd. (Ghattas, 2020).

Kraljevina Savdska Arabija v zadnjih letih, predvsem odkar se sooča s številnimi (vojaškimi) izzivi v Jemnu in Siriji, poskuša znova uveljaviti svojo moč, tudi s spreminjanjem ambivalentne regionalne usmeritve Libanona, predvsem z različnimi finančnimi ter diplomatskim pritiski in ukrepi (Berti, 2016; Kamrava, 2018). Februarja 2016 je Savdska Arabija tako zadržala kar štiri milijarde dolarjev vreden paket pomoči Libanonu (tri milijarde dolarjev vreden paket vojaške pomoči za libanonsko vojsko za nakup francoskega orožja in eno milijardo dolarjev, ki naj bi bili namenjeni libanonskemu varnostnemu sektorju). S preklicem te pomoči se je Savdska Arabija želela maščevati za uradno nevtralnost libanonske vlade $\mathrm{v}$ napetostih med kraljevino in Iranom (Berti, 2016; Kamrava, 2018). Savdska Arabija je vodila tudi kampanjo držav GCC in Arabske lige, v okviru katere so Hezbolah razglasili za »teroristično organizacijo« in s tem želeli omejiti njen vpliv (Kamrava, 2018). Savdska Arabija je svoje državljane pozvala tudi, naj se vzdržijo 
potovanj v Libanon, ki je že zgodovinsko zelo priljubljena destinacija med zalivskimi turisti (Berti, 2016). Poleg tega je 4. novembra 2017 takratni predsednik libanonske vlade Hariri med obiskom v Savdski Arabiji napovedal svoj odstop in sprožil razpravo, ali ga je savdski režim prisilil k odstopu, ker se ni bil pripravljen ostreje soočiti s Hezbolahom. Čeprav so uradniki v Libanonu trdili, da je Hariri talec savdskih oblasti, je sam te domneve zanikal in svoj odstop pripisal vmešavanju Irana in aktivnostim Hezbolaha ter dodal, da se boji poskusa atentata. Kljub temu pa je Hariri 22. novembra 2017, potem ko je obiskal še Francijo in Egipt ter se vrnil v Libanon, svoj odstop preložil (Al Jazeera, 2017). Čeprav hoče Savdska Arabija s tovrstnimi akcijami zasledovati svoje strateške interese ter okrepiti svoj vpliv v Libanonu in regiji, pa številni primeri kažejo, da so dejanski učinki ravno nasprotni. S svojimi ukrepi Savdska Arabija namreč šibi svoje (sunitske) zaveznike $\mathrm{v}$ Libanonu ter posledično zmanjšuje svoj vpliv in ustvarja prostor za okrepljen vpliv svojih nasprotnikov - Irana in Hezbolaha -, ki se že manifestira $\mathrm{v}$ številnih primerih.

Iran je na primer ponudil okrepitev in podporo libanonski vojski, ko je Savdska Arabija zadržala že obljubljeno vojaško pomoč (Berti, 2016). Negativne posledice savdskih ukrepov čutijo tudi njihovi največji zave104 zniki, predvsem Saad Hariri in njegova politična stranka Future Movement. Savdski režim je namreč stranko pozval k ostrejšemu odnosu do Hezbolaha, a se je stranka zaradi politične in varnostne situacije začela celo približevati Hezbolahu. Ker Haririjeva drža torej ni zadostila zahtevam Savdske Arabije po omejevanju vmešavanja Hezbolaha, je Hariri izpadel šibak in izoliran (Berti, 2016). Takšna podoba je bila še posebej nezaželena v trenutku, ko se je Haririjeva koalicija 14. marca že tako soočala z notranjimi delitvami zaradi predsedniških volitev, Hariri pa je doživljal tudi padec podpore znotraj lastne sunitske skupnosti (Berti, 2016).

Tako kot Savdska Arabija skuša tudi Iran svoje sfere moči v regiji razširiti $s$ pomočjo Libanona, predvsem prek Hezbolaha. Medtem ko so se iransko-libanonski odnosi vzpostavili že pred ustanovitvijo modernega Libanona in segajo vse do 16. stoletja, je bil prelomni trenutek, ki je vplival na transformacijo medsebojnih odnosov, znamenita iranska revolucija leta 1979, ki je poglobila iranske odnose z libanonsko šiitsko skupnostjo. Ta odnos je zelo močno vplival na libanonsko notranjo politiko, predvsem od leta 1982 dalje, ko je Iran po izraelski invaziji na Libanon spodbudil ustanovitev Hezbolaha ali t.i. »Božje stranke«. Vse odtlej Iran dojema Hezbolah, in ne libanonske države, kot svojega glavnega libanonskega sogovornika, ki dejansko predstavlja najuspešnejši izvoz iranske revolucije (Hokayem, 2015; Feltman, 2019). Iran je zagotovil denar (Iran naj bi Hezbolahu letno nakazal od 200 do 700 milijonov dolarjev) in najsodobnejše orožje, ki je Hezbolah preobrazilo v eno najmočnejših milic v domačem in regionalnem 
okolju ter pomembno organizacijo, ki velikemu delu libanonskega prebivalstva zagotavlja blaginjo, socialne storitve in varnost. V zameno Hezbolah podpira iranske zunanje operacije in torej služi kot podaljšek iranske zunanje politike in instrument njihove varnostne politike predvsem proti Izraelu in ZDA (Hokayem, 2015; Ioan Pop and Silber, 2020). A odnos med Iranom in Hezbolahom je precej kompleksnejši, saj mora Hezbolah igrati več domačih vlog (politična stranka, ki je del parlamenta in vlade; socialna organizacija; milica, ki zagotavlja varnost) in regionalnih vlog ter si posledično ne more dovoliti, da bi bil zgolj poslušni deležnik v rokah Irana.

V kontekstu argumentov proti prevladujočim, a precej poenostavljenim diskurzom o sektaštvu je pomembno poudariti, da so razmerja med Iranom, šitsko skupnostjo v Libanonu in libanonsko državo precej kompleksna in dinamična. Najprej je treba izpostaviti, da se iranske podpore Hezbolaha ne prevaja avtomatično $\mathrm{v}$ zvestobo ali nedvoumno podporo Iranu med libanonsko šiitsko skupnostjo. Medtem ko večina šiitov v Libanonu ceni iransko podporo v odnosu do Izraela, imajo libanonski šiiti precej različne poglede na iranski politični model in pomisleke o njihovih dolgoročnih namenih (Hokayem, 2015). Uradni odnosi med državama pa prav tako niso stabilni, temveč so večinoma odvisni od naravnanosti libanonske vlade do Hezbolaha.

Kot smo že izpostavili, je na notranje politike in delitve znotraj Libanona močno vplivala tudi državljanska vojna v Siriji, kjer svojo moč in vpliv kažeta tako Savdska Arabija (ki podpira opozicijo) kot Iran (ki podpira režim predsednika Al-Assada), vpletajo pa se tudi libanonski akterji. Čeprav je libanonska vlada v primeru sirskega konflikta uradno želela ostati nevtralna, so libanonski sunitski akterji podprli opozicijske skupine v Siriji - čeprav v relativno razdrobljeni, neformalni in precej omejeni obliki -, intenzivneje pa se je v vojno vpletel Hezbolah, ki ga krivijo, da je sirijsko vojno pripeljal tudi v Libanon. Hezbolah se je v vojno vpletel s svojo vojsko predvsem zato, ker bi padec Assadovega režima pomenil odstranitev ključnega partnerja Hezbolaha v regiji ter vplival na zavezništvo z Iranom. Hkrati pa bi krepitev sirijskih opozicijskih skupin na libanonsko-sirijski meji ogrozila točke, ki jih nadzoruje Hezbolah, in obmejne točke, kjer prevladujejo šitske skupnosti (van Veen, 2015). A intervencije Hezbolaha so močno poslabšale njegovo kredibilnost tako med splošno populacijo kot tudi med političnimi elitami ter vplivale na porast radikalizacije znotraj Libanona. Hezbolah je na sirsko fronto poslal več kot pet tisoč svojih pripadnikov in tako pomembno pripomogel h krepitvi režima v Siriji, a je kljub temu precenil svoje zmogljivosti hkratnega bojevanja tako v Siriji kot v Libanonu (van Veen, 2015; Harris, 2016).

Medtem ko se čezmejni učinki sirske vojne v Libanonu analizirajo predvsem skozi vidik sirskih beguncev (Libanon je od začetka vojne v Siriji leta 2011 sprejel več kot milijon beguncev), radikalizacije znotraj sunitske 
skupnosti, obmejnih konfliktov ipd., precej manj študij raziskuje, kako sirski konflikt in posledično intenzivni pritok beguncev izrabljajo politične elite za zasledovanje lastnih agend (van Veen, 2015; Carpi et al., 2016; intervju 12, 2016). Politični in medijski diskurzi sirijske begunce v veliki meri portretirajo kot grožnjo ter $\mathrm{s}$ tem opravičujejo ukrepe in akcije neformalnih varnostnih akterjev, predvsem političnih strank, ki na določenih območjih izvajajo ukrepe, s pomočjo katerih ostajajo na oblasti (Carpi et al., 2016).

Na krepitev političnih delitev znotraj Libanona je močno vpliv tudi iranski jedrski sporazum z ZDA in ostalimi velesilami iz leta 2015. Koalicija 8. marca, v kateri sta dominantni stranki ravno Hezbolah in krščanska Free Patriotic Movement, je sporazum podprla, medtem ko so bili nekateri člani koalicije 14. marca mnenja, da bi lahko dogovor okrepil iranski vpliv in iransko podporo njihovim zaveznikom, predvsem Hezbolahu (Hokayem, 2015; Harris, 2016).

V okviru širšega pregleda silnic v regiji, ki vplivajo na Libanon, lahko zaključimo, da naraščajoči pritiski Savdske Arabije in iransko pokroviteljstvo nad Hezbolahom močno vplivajo na zaostrovanje napetosti med sektami in poglabljajo politični razkol med koalicijama 8. in 14. marca, kar pomeni veliko oviro pri razreševanju obstoječih kriz.

\section{Sklep}

Libanon se sooča z eno izmed največjih političnih, ekonomskih in finančnih kriz od začetka državljanske vojne, ki so jo v letu 2020 dodatno okrepile še posledice pandemije virusa covid-19 in silovita eksplozija v bejrutskem pristanišču. Tako se je znova izkazalo, da imajo dominantne paradigme in prevladujoči diskurzi številne pomanjkljivosti ter da moramo vzroke tovrstnih kriz iskati $\mathrm{v}$ sistemskih patologijah libanonske politike, ki se krepijo že najmanj tri desetletja. Hranjenje eksplozivnega materiala v glavnem in močno naseljenem mestu Libanona je dejansko simbol dinamik in institucionalne šibkosti države, ki jo prežema globok klientelizem, ki dejansko že meji na kriminalni mafijski sistem ter posledično potrebuje intenzivno transformacijo na številnih ravneh.

Pričujoč članek prikaže, kako se politični model sekt in upravljanje manifestirata $v$ praktično vseh družbenih podsistemih in tako preprečujeta pojav močne politične in socioekonomske alternative ter prispevata $\mathrm{k}$ reprodukciji in krepitvi sektaštva. Klientelističen, koruptiven ter netransparenten in neodgovoren sistem, ki v osnovi temelji na delitvi moči med osrednjimi verskimi skupnostmi/sektami, je uspel prodreti globoko v različne družbene podsisteme: političnovarnostnega, socioekonomskega, civilnodružbenega in ideološkega. V okviru raziskave smo uspeli identificirati številne dinamike in mehanizme, ki v medsebojni kombinaciji prispevajo k ohranjanju 
vladajoče politične elite. Od širjenja neučinkovitega javnega sektorja, namenskega slabljenja večine državnih institucij do močno razpršenega klientelizma, v okviru katerega se distribucija blaginje in varnosti zagotavlja prek sektaških neformalnih kanalov in na podlagi državnih resursov. Od ustvarjanja taktičnega socioekonomskega okolja in uporabe sistemskih tehnik discipliniranja, zaradi katerih so prebivalci Libanona praktično prisiljeni sprejeti identitete sekte in ponotranjiti nepotistične vzorce delovanja do represije varnostnih organov, kooptacije večine civilnodružbenih organizacij in intenzivne sektarianizacije. Vse notranje dinamike in mehanizme pa dodatno še krepi regionalno geopolitično dogajanje, predvsem vmešavanje Savdske Arabije in Irana.

Članek torej prikaže, da je problematika konfliktov in kriz kot tudi demokratičnega deficita $v$ Libanonu izjemno kompleksna ter zahteva razumevanje, da ti nastajajo kot posledica številnih, predvsem horizontalnih razrednih delitev in politik delitve ter ne (zgolj) zaradi sektaških identitet. Ključni igralci konfliktov, kriz in demokratičnega deficita torej niso posamezne sekte, temveč sektaške politične stranke in koalicije elit, ki so uspele iznajti in uporabljati številne mehanizme, ki jim omogočajo obstati na oblasti.

\section{LITERATURA}

Adwan, Charles (2004): Corruption in Reconstruction: The Cost of 'National

Consensus' in Post-War Lebanon. Washington: Center for International Private Enterprise.

Alami, Mona (2019): Lebanon's Free Fall. Washington, DC: Carnegie Endowment for International Peace.

Atzili, Boaz (2010): State Weakness and „Vacuum of Power» in Lebanon, Studies in Conflict and Terrorism, 33 (8): 757-782.

Barak, Oren (2012): Representation and stability in post-war Lebanon. Representation 48 (3): 321-333.

Baytiyeh, Hoda (2019): Lebanon's Power-Sharing System and the Rise of Sectarianism, Peace Review 31 (2): 223-230.

Belhadj, Souhad, Chris van der Borgh, Rivke Jaffe, Megan Price, Nora Stel and Michael James Warren (2015): Plural security provision in Beirut - Policy Brief. Hague: The Knowledge Platform Security and Rule of Law.

Berti, Benedetta (2016): Saudi Brinkmanship in Lebanon. Washington, DC: Carnegie Endowment for International Peace.

Bieber, Florian (2003): The Challenge of Institutionalizing Ethnicity in the Western Balkans: Managing Change in Deeply Divided Societies. European Yearbook of Minority Issues Online 3 (1): 1-34.

Bou Khater, Lea (2020): Poverty Targeting is not the Solution for Much Needed Social Policy. Beirut: The Lebanese Center for Policy Studies.

Cammett, Melani and Sukriti Issar (2010): Bricks and Mortar Clientelism: Sectarianism and the Logics of Welfare Allocation in Lebanon. World Politics 62 (3): 381-421. 
Carpi, Estella, Mariam Younes and Marie-Noëlle Abi Yaghi (2016): (In)formal hybrid security in Lebanon. Beirut: Lebanon Support.

Clark, Janine and Bassel F. Salloukh (2013): Elite strategies, civil society, and sectarian identities in postwar Lebanon. International Journal of Middle East Studies 45 (4): 731-749.

De Elvira, Ruiz (ur), Laura Christoph H. Schwarz (ur.), Irene Weipert-Fenner (ur.) (2019): Clientelism and Patronage in the Middle East and North Africa Networks of Dependency. London and New York: Routledge.

Egan, Martyn and Paul Tabar (2016): Bourdieu in Beirut: Wasta, the State and Social Reproduction in Lebanon, Middle East Critique 25 (3): 249-270.

Fakhoury, Tamirace (2019): Power-sharing after the Arab Spring? Insights from Lebanon's Political Transition, Nationalism and Ethnic Politics 25 (1): 9-26.

Gaub, Florence (2016): Civil military relations in the MENA: Between fragility and resilience. Paris: EU Institute for Security Studies.

Geha, Carmen (2019): Sharing Power and Faking Governance? Lebanese State and Non-State Institutions during the War in Syria, The International Spectator 54: 4, 125-140.

Ghalioun, Burhan (1979; 2012): The Sectarian Question and the Problem of Minorities. Doha: ACRPS.

Ghattas, Kim (2020): Black Wave: Saudi Arabia, Iran, and the Forty-Year Rivalry That Unraveled Culture, Religion, and Collective Memory in the Middle East. New York: Henry Holt and Co.

Gray, Matthew (2019): Theorising politics, patronage, and corruption in the Arab monarchies of the Gulf. V De Elvira, Ruiz (ur), Laura Christoph H. Schwarz (ur.), Irene Weipert-Fenner (ur.), Clientelism and Patronage in the Middle East and North Africa Networks of Dependency, 47-67. London and New York: Routledge.

Guelke, Adrian (2012): Politics in Deeply Divided Societies. Cambridge: Polity Press.

Haase, Thomas W. (2018): A Challenging State of Affairs: Public Administration in the Republic of Lebanon, International Journal of Public Administration 41 (10): 792-806.

Haddad, Simon (2010): Cultural diversity and sectarian attitudes in postwar Lebanon, Journal of Ethnic and Migration Studies 28 (2): 291-306.

Harris, William (2016): Republic of Lebanon. V Mark Gasiorowski (ur.) and Sean L. Yom (ur.), The Government and Politics of the Middle East and North Africa, 79-110. Boulder: Westview Press.

Hanafi, Sari (2012): The Arab revolutions; the emergence of a new political subjectivity. Contemporary Arab Affairs 5 (2): 198-213.

Hazbun, Waleed (2016): Assembling security in a "weak state«: the contentious politics of plural governance in Lebanon since 2005. Third World Quarterly 37 (6): 1053-1070.

Hokayem, Emile (2015): Iran and Lebanon. Dostopno prek https://iranprimer. usip.org/sites/default/files/PDF\%20Iran\%20Region_Hokayem_e banon.pdf, 4. 8. 2020. 
Ioan, Pop, and Mitchell D. Silber (2020): Iran and Hezbollah's Pre-Operational Modus Operandi in the West. Studies in Conflict and Terrorism 2020: 1-24.

Jarstad, Anna (2009): The Prevalence of Power-Sharing: Exploring the Patterns of Post-Election Peace. Africa Spectrum 44 (3): 41-62.

Jeffrey, Feltman (2019): Hezbollah: Revolutionary Iran's most successful export. Washington, DC: The Brookings Institution.

Kamrava, Mehran (2018): Hierarchy and Instability in the Middle East Regional Order. International Studies Journal 14 (4): 1-35.

Leenders, Reinoud (2016): The First Time as Tragedy, the Second as Farce? Lebanon's Nascent Petroleum Sector and the Risks of Corruption, Mediterranean Politics 21 (2): 268-291.

Lijphart, Arend (1969): Consociational democracy. World Politics 21.

Majed, Rima (2017): Why the Lebanese support the same sectarian leaders. Dostopno prek https://www.aljazeera.com/indepth/features/2017/03/lebanese-support-sectarianleaders-170312084011811.html, 3. 7. 2020.

Majed, Rima (2019): What is So Deep About "Deeply-Divided Societies"? Dostopno prek https://lebanesestudies.com/papers/what-is-so-deep-about-deeply-dividedsocieties/what-is-so-deep-about-deeply-divided-societies/, 5. 7. 2020.

Majed, Rima (2020): In Defense of Intra-Sectarian Divide: Street Mobilization, Coalition Formation, and Rapid Realignments of Sectarian Boundaries in Lebanon. Social Forces July (2020): 1-27.

Makdisi, Samir, and Youssef El-Khalil (2013): Lebanon: The Legacy of Sectarian Consociationalism and the Transition to a Fully-fledged Democracy. Beirut: Issam Fares Institute for Public Policy and International Affairs American University of Beirut.

McCulloch, Allison (2014): Consociational settlements in deeply divided societies: The liberal-corporate distinction. Democratization 21 (3): 501-518.

Mounzer, Lina (2020): We Lebanese Thought We Could Survive Anything. We Were Wrong. Dostopno prek https:/www.nytimes.com/2020/08/03/opinion/ lebanon-coronavirus-economy.html?fbclid=IwAR0jDM2aqLfpQBu7J7NQukc_ FcBhoQexTU_nUPmj7bK31bdcLTr6ptSnaDQ, 5. 8. 2020.

Nagle, John (2016): Between entrenchment, reform and transformation: ethnicity and Lebanon's consociational democracy. Democratization 23 (7): 1144-1161.

Nagle, John, Mary-Alice Clancy (2019): Power-sharing after Civil War: Thirty Years since Lebanon's Taif Agreement. Nationalism and Ethnic Politics 25 (1): 1-8.

Nucho, Joanne Randa (2017): Everyday Sectarianism in Urban Lebanon: Infrastructures, Public Services, and Power. Princeton: Princeton University Press.

Roeder, Philip G. (ur.), Donald Rothchild (ur.) (2005): Sustainable Peace: Power and Democracy after Civil Wars. London: Cornell University Press.

Salamey, Imad and Rhys Payne (2008): Parliamentary Consociationalism in Lebanon: Equal Citizenry vs. Quotated Confessionalism. The Journal of Legislative Studies 14 (4): 451-473.

Salamey, Imad (2009): Failing consociationalism in Lebanon and Integrative options. International Journal of Peace Studies 14 (2): 83-105. 
Salibi, Kamal (1990): A House of Many Mansions: The History of Lebanon Reconsidered. Oakland: University of California Press.

Salloukh, Bassel F., Rabie Barakat, Jinan S. Al-Habbal, Lara W. Khattab, Shoghig Mikaelian (2015): The Politics of Sectarianism in Postwar Lebanon. London: Pluto Press.

Salloukh, Bassel F. (2019): Taif and the Lebanese State: The Political Economy of a Very Sectarian Public Sector. Nationalism and Ethnic Politics 25 (1): 43-60.

Salloukh, Bassel F. (2020): What happens now to Lebanon's government? Here's why real reforms may be unlikely. Dostopno prek https://www.washingtonpost.com/politics/2020/08/18/what-happens-now-lebanons-government-hereswhy-real-reforms-may-be-unlikely/, 19. 8. 2020.

Smooha, Sammy and Theodor Hanf (1992): The Diverse Modes of ConflictRegulation in Deeply Divided Societies. International Journal of Comparative Sociology 33 (1-2): 26-47.

Traboulsi, Fawwaz (2014): Social Classes and Political Power in Lebanon. Beirut: Heinrich Boell Foundation - Middle East.

Van Den Berghe, P. L. (2002): Multicultural democracy: can it work? Nations and Nationalism, 8: 433-449.

Van Veen, Erwin (2015): Elites, power and security: How the organization of security in Lebanon serves elite interest. Hague: Knowledge Platform.

Al Jazeera (2017): All eyes on Beirut as Saad Hariri returns. Dostopno prek https:// www.aljazeera.com/news/2017/11/saad-hariri-returns-lebanonshock- resignation-171121213504403.html, 3. 8. 2020.

Human Rights Watch (2020). Dostopno prek https://www.hrw.org/blog-feed/lebanon-protests, 10. 8. 2020.

Intervju 1 (2016). Intervju s predstavnikom policije (ISF), Bejrut, 27. 5. 2016.

Intervju 2 (2016). Intervju s predstavnikom vojske (LAF), Bejrut, 30. 5. 2016.

Intervju 3 (2016). Intervju s predstavnikom Generalnega sekretariata (GS), Bejrut, 7. 6.2016.

Intervju 4 (2016). Intervju s predstavnikom ministrstva za notranje zadeve, Bejrut, 19. 5. 2016.

Intervju 5 (2016). Intervju s predstavnikom politične stranke, Bejrut, 20. 5. 2016. Intervju 6 (2016). Intervju s predstavnikom politične stranke, Bejrut, 10. 5. 2016. Intervju 7 (2016). Intervju s predstavnikom politične stranke, Bejrut, 7. 6. 2016. Intervju 8 (2016). Intervju s strokovnjakom raziskovalnega centra v Bejrutu, Bejrut, 12. 5.2016.

Intervju 9 (2016). Intervju s profesorico politologije na American University of Beirut (AUB) in predstavnico civilne družbe, 2. 6. 2016, Bejrut, 2016.

Intervju 10 (2016). Intervju s profesorjem na Sagesse University (Faculty of Law), Bejrut, 18. 5. 2016.

Intervju 11 (2016). Intervju s predstavnico mednarodne nevladne organizacije, Bejrut, 26. 5. 2016. 
Intervju 12 (2016). Intervju s predstavnico libanonske nevladne organizacij, Bejrut, 6. 6.2016.

Intervju 13 (2016). Intervju s predstavnikom libanonske nevladne organizacije, Bejrut, 8. 6. 2016.

Intervju 14 (2016). Intervju s predstavnico libanonske nevladne organizacije, Bejrut, 11. 5. 2016.

Intervju 15 (2016). Intervju s predstavnikom libanonske nevladne organizacije, Bejrut, 13. 6. 2016.

Intervju 16 (2016). Intervju s predstavnikom delegacije EU-ja v Libanonu, Bejrut, 6. 6.2016.

Intervju 17 (2016). Intervju s profesorjem na American University of Beirut (AUB), Bejrut, 13. 5. 2016.

Intervju 18 (2016). Intervju s profesorjem na American University of Beirut (AUB), Bejrut, 27. 4. 2016.

Intervju 19 (2016). Intervju s profesorjem na American University of Beirut (AUB), Bejrut, 25. 4. 2016.

Intervju 20 (2016). Intervju s profesorjem na American University of Beirut (AUB), Bejrut, 9. 5. 2016.

Intervju 21 (2016). Intervju s profesorjem na Lebanese University, Bejrut, 10. 5 2016.

Intervju 22 (2016). On-line intervju s profesorjem na Georgetown University, Bejrut/Washington, 9. 5. 2016.

Lebanon Support (2019): Conflict Analysis Project. Dostopno prek https://civilsociety-centre.org/cap, 1. 7. 2020.

Middle East Report (2015): Lebanon's Self-Defeating Survival Strategies. Dostopno prek https://www.crisisgroup.org/middle-east-north-africa/eastern-mediterranean/lebanon/lebanon-s-self-defeating-survival-strategies, 2. 7. 2020. 